\title{
ACI TAT ALGILANMA MEKANIZZMASI, SÜT ÜRÜNLERİNDE PEPTİT KAYNAKLI ACILIĞIN GİDERİLMESİ VE GÜNCEL YAKLAŞIMLAR
}

\author{
Hacer Gürkan*, Ali Adnan Hayaloğlu \\ İnönü Üniversitesi, Mühendislik Fakültesi, Gıda Mühendisliği Bölümü, Malatya, Türkiye
}

Geliş / Received: 19.11.2019; Kabul / Accepted: 22.02.2020; Online bask1 / Published online: 13.03.2020

Gürkan, H., Hayaloğlu, A.A. (2020). Ac1 tat alg1lanma mekanizması, süt ürünlerinde peptit kaynaklı acıllğın giderilmesi ve güncel yaklaşımlar. GID $A$ (2020) 45(2) 299-314 doi: 10.15237/gida.GD19151

Gürkan, H., Hayaloğlu, A.A. (2020). Bitter taste perception mechanism, removal of bitterness caused by peptide in dairy products and current approaches. GIDA (2020) 45(2) 299-314 doi: 10.15237/gida.GD19151

\section{ÖZ}

Protein bakımından zengin gidaların hidrolizasyona uğraması sonucu acı tattan sorumlu peptitler oluşabilmektedir. Acılık algisı, acı tat reseptörlerinin uyarılması ve sinir sistemi ile beyne gönderilen sinyalin yorumlanması ile oluşmaktadır. Süt ürünleri çoğu zaman acı peptitlerle karakterize edilmektedir. Yapılan çalışmalarda peynirde tanımlanan acı peptitlerin genellikle $a_{s 1}{ }^{-}$ve $\beta$-kazein kaynaklı olduğu belirtilmiştir. Protein hidrolizatlarının acı tat yoğunluğu peptitin hidrofobisitesine, hidrofobik amino asit sayısına ve zincir uzunluğuna bağlı olarak değişmektedir. Peynirlerde olgunlaşmayı hızlandırırken, acı tat kusurlarının oluşumunu engellemek için son zamanlarda aminopeptidaz, karboksipeptidaz ve starter kültürle birlikte yardımcı kültürlerin yer aldığı metotlar kullanılmaktadır. Bu derlemede; acı peptitlerin oluşumu ve algılanma mekanizması açıklanmış ve aclık giderme yöntemleri ile ilgili güncel çalışmalar sunulmuştur.

Anahtar kelimeler: Act peptit, kazein, starter kültür, proteoliz, kimozin.

\section{BITTER TASTE PERCEPTION MECHANISM, REMOVAL OF BITTERNESS CAUSED BY PEPTIDE IN DAIRY PRODUCTS AND CURRENT APPROACHES}

\section{ABSTRACT}

Peptides responsible for bitter taste may form, as a result of the hydrolysis of protein-rich foods. The perception of bitterness is formed by the stimulation of bitter taste receptors and the interpretation of the signal sent to the brain through the nervous system. Dairy products are often characterized by bitter peptides. In studies conducted, it has been stated that the bitter peptides identified in cheese are generally originated from $a_{51}$ and $\beta$-casein. The bitter taste intensity of protein hydrolysates varies depending on the hydrophobicity of the peptide, the number of hydrophobic amino acids and its the chain length. While accelerating ripening in cheeses, methods including aminopeptidase, carboxypeptidase and adjunct cultures with starter culture have been used recently to prevent the formation of bitter taste defects. In this review; the formation and perception mechanism of bitter peptides has been explained and current studies on bitter removal methods have been presented. Keywords: Bitter peptide, casein, starter culture, proteolysis, chymosin.

\footnotetext{
${ }^{*}$ Yazışmalardan sorumlu yazar/Corresponding author: 


\section{GİRİ̧̧}

Protein; karbon, hidrojen, oksijen, azot ve genellikle sülfür içeren peptit bağlantılarındaki amino asit kombinasyonlarından oluşan karmaşık bir organik yapı olarak tanımlanmaktadır (Dorian, 1978). G1dalardaki proteinlerin en önemli fonksiyonu, g1da maddelerinin kendine özgü karakteristik yapısını sağlamak ve/veya stabilize etmektir (Foegeding ve Davis, 2011). Ayrica gida proteinleri, daha fonksiyonel veya besleyici ürünlere enzimatik dönüşüm için iyi bir substrat kaynağıdır (Aluko, 2017). Son zamanlarda tüketilen gıdaların sağlıklı yaşam sürdürmede etkili olduğu belirtilmiştir. $\mathrm{Bu}$ nedenle tüketicilerin besleyici gıda kaynaklarına taleplerini artırması, gida bileşiminde bulunan proteinlerin türevi olan biyoaktif peptitlerin önemini artırmıstır (Mohan vd., 2015).

Biyoaktif peptitler, proteinlerin enzimatik proteolizi (gastrointestinal sindirim, proteolitik enzimler kullanilarak in vitro hidroliz) sirasinda ve ayrıca gıda işleme (pişirme, fermentasyon, olgunlaşma) sırasında açığa çıabilmektedir (Bhopale, 2016; Daliri vd., 2017). Biyoaktif peptitler hipertansiyon, diyabet, obezite ve hatta kanser gibi metabolik bozuklukların etkin bir şekilde yönetimi için ilaçlara karşı doğal terapötik alternatif olarak önerilmiştir. Protein hidrolizi, istenen fonksiyonel veya biyoaktif özelliklere sahip peptitler açı̆ga çıaracak şekilde düzenlenebilmekte, ancak aşırı ve kontrolsüz hidroliz sonucu arzu edilmeyen lezzette, acı tada sahip peptitler oluşabilmektedir (Aluko, 2017; Aryee vd., 2018; Meng vd., 2018). Normalde, proteinlerin tatsı olduğu kabul edilmekte (Solms, 1969) ancak, bazı enzimlerle proteolize uğraması sonucu açığa çıkan hidrolizatların acı tat verdiği belirtilmiştir (Aluko, 2017). Ac1 peptit oluşumunda kazein birincil derecede öneme sahiptir (Guigoz ve Solms, 1976). Bu nedenle ac1 peptitlerin, çoğunlukla süt ürünlerinden izole edildiği belirtilmektedir (Aluko, 2017).

$\mathrm{Bu}$ derlemede; acı peptitlerin oluşumu ve alg1lanma mekanizması, acılık giderme yöntemleri ile süt ürünlerinde yapılan güncel acı peptitler ile ilgili çalışmalar sunulmuştur.

\section{ACI TADIN ALGILANMA MEKANIZMASI}

Gıda seçimini ve dolayısıyla beslenme durumunu ve sağlığ1 önemli derecede etkileyen tat alg1s1, bireyler arasında büyük ölçüde farkll11k göstermektedir (Melis ve Barbarossa, 2017). Tat, dilin yüzeyinde ve ağız ile boğazın dile yakın bölgelerinde bulunan tat tomurcukları ile tat veren bileşiğin sudaki çözeltisinin temasa geçmesi ile algilanmaktadır (Karadeniz, 2000). Dil yüzeyine dizilmiş durumda bulunan tat tomurcukları sayısı itibari ile yaş ilerlemesine bağlı olarak azalış göstermekte ve bu sayı bir insanda 4000 ile 9000 arasında değişebilmektedir (Batu, 2017). Tat tomurcuklar1, tat duyusuna aracilik eden reseptörler içeren dil yüzeyinde bulunan yapılardır (Vummaneni ve Nagpal, 2012). Her bir tat tomurcuğu 50-100 adet tat hücresi içermekte ve her bir hücrenin tepe noktasinda tat reseptörleri yer almaktadır (Kazaz vd., 2019). Ancak insanlarda, tat tomurcuklarındaki TAS2R gen ailesinin 25 üyesi acı tat reseptörleri olarak işlev görebilmektedir. Tat algilama yapis1 ve tat reseptörlerindeki acı tadın alg1lanma mekanizması Şekil 1'de gösterilmiştir. Ac1 tat veren bileşikler, dilin yan ve arka yüzeylerinde foliat ve sirkumvallat papilla içindeki reseptörlerle etkileşime girdiğinde algılanmaktadır (Kim vd., 2014; Fábián vd., 2015). Ac1 tadın algilanmas1, acıyı ortaya çıkaran bileşiklerin tat reseptör hücrelerinin apikal yüzeyindeki tat gözeneğinden çıkıntı yapan reseptörlere bağlandıklarında, G proteinine bağlı bir reseptör sinıfi olan GPCR'lerin aktivasyonuna ve ardından $\mathrm{G}_{\beta \gamma}$-alt ünitesinin $\mathrm{G}_{a \beta \gamma}$-hetetrimerik reseptöründen serbest birakılmasına yol açan kademeli bir sinyal iletimi oluşturduğunda meydana gelmektedir. $\mathrm{G}_{\beta \gamma}$ -alt ünitesinin serbest birakılması ile hücre içi inositol trifosfat $\left(\mathrm{IP}_{3}\right)$ ve diaçilgliserol (DAG) üreten fosfolipitler, fosfotidil inositol 4,5bisfosfat $\left(\mathrm{PIP}_{2}\right)$ 'in parçalanmasına yol açan fosfolipaz C (PLC-B2)'1 aktive etmektedir. Artan inositol-1,4,5- trifosfat $\left(\mathrm{IP}_{3}\right)$ seviyeleri, $\mathrm{IP}_{3}$ reseptörlerini uyarır ve hücre içi $\mathrm{Ca}^{+2}$ depolarının salınımını tetiklemektedir. Buradan, geçici reseptör potansiyel katyon kanalının (TRPM5) aktivasyonu meydana gelmekte, bu da $\mathrm{Na}^{+}$akışına ve ardından reseptör hücre depolarizasyonuna neden olmaktadır. Elde edilen bu bilgi daha sonra 
nörotransmiterlerin salgılandığ1 çıktı hücrelerine, yani adenozin trifosfat (ATP)'a iletilmektedir. Nörotransmitterlerin sinir liflerine salınmasi ile kimyasal sinyali beyindeki bilgi işlem merkezlerine taşıyan bir aksiyon potansiyeli oluşmaktadır. Buradan, beynin limbik sistemi sinyali yorumlamakta ve acı lezzetin kalitesi ve yoğunluğu bilişsel olarak algılanmaktadır (Gaudette ve Pickering, 2013). Sonuç olarak, tat reseptör hücreleri, dilin yüzeyinde herhangi bir tat maddesi tarafından uyarıldığında tat hücresinin içi ve dışı arasındaki mevcut elektrik yükü değişmektedir. Bu değişim ise bir elektriksel sinir impulsu olarak sinirlere iletilerek beyne ulaştırılmakta ve beyinde tat duyusu oluşmaktadır (Miişoğlu ve Hayoğlu, 2005).

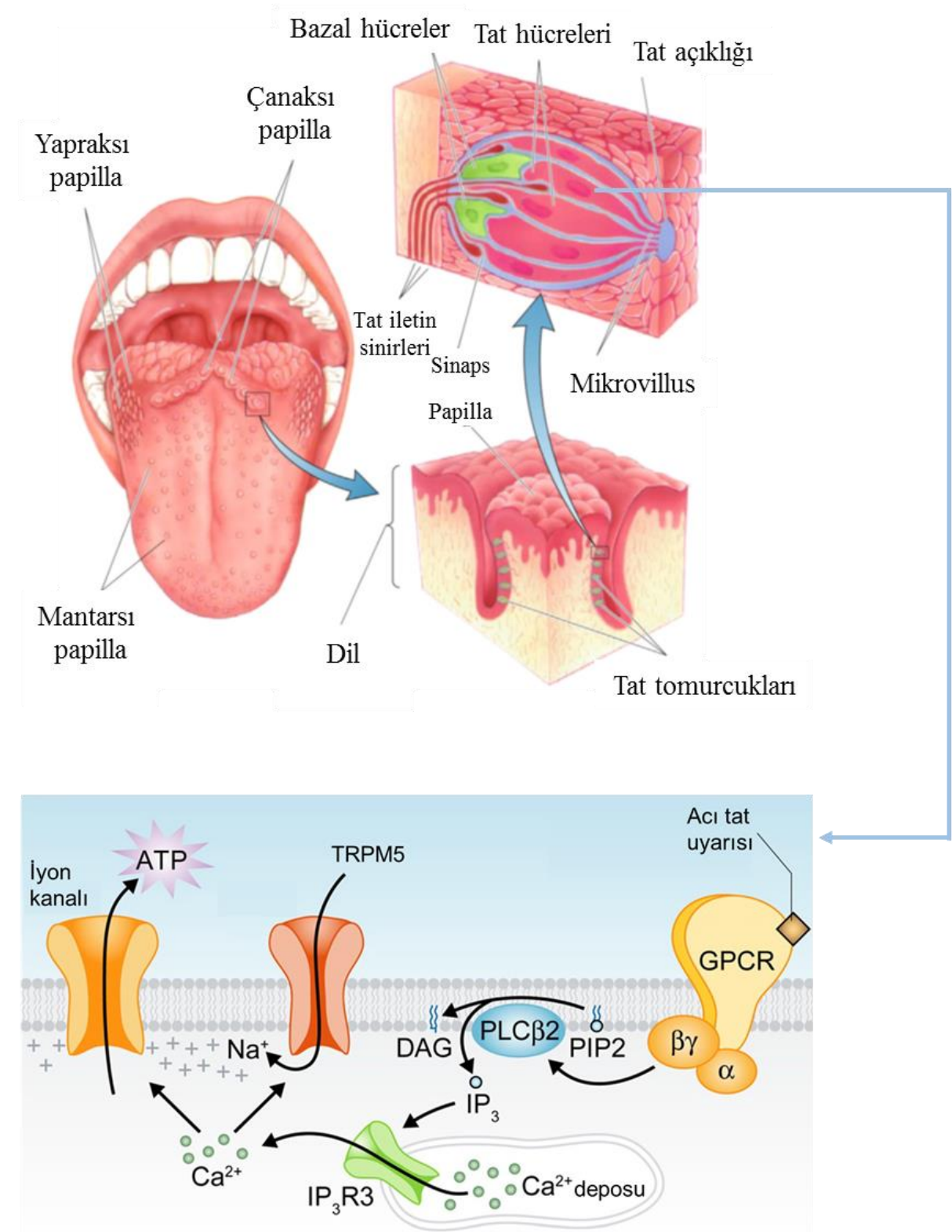

Şekil 1. Tat alg1lama yapis1 ve mekanizmas1 (Chaudhari ve Roper, 2010; Wu vd., 2014) 


\section{PEPTİT KAYNAKLI ACILIĞIN GİDERİLMESİ VE KONTROL YÖNTEMLERİ}

Genellikle acılık giderme işlemine acıllk veren peptitlerin seviyesini azaltıc1 yöntemler ile yaklaşılmışırır. Herhangi bir peptitin acllı̆ını azaltmak için uygulanan yöntemlerden biri, enzimatik hidroliz ile üretilen protein hidrolizatının enzimler ile daha ileri derecede hidrolizidir. Bu işlem, oldukça etkili bir yöntem olmasına rağmen, ilave enzimlerin gerekliliği nedeniyle maliyetlidir. Ayrıca, ileri derece hidrolizasyona bağlı olarak ilk etapta oluşabilecek aktif peptitlerin özelliklerinin yanlışıkla kaybolması riskini de taşımaktadır (Chakrabarti vd., 2018). Başka bir yöntem ise, acı peptitleri jel ayırma, alkol ekstraksiyonu, silika jel üzerinde kromatografi ve izoelektrik çökeltme gibi bir veya daha fazla teknik içeren kompleks bir karışımdan "elemek" olmuştur. Ancak bu yöntemlerin her birinin yararları olsa da, zaman ve masraf açısından ticari bir üretim programında yer bulamamışır. Alternatif bir başka yaklaşım ise, çeşitli şekerler, tuzlar ve nükleotitler gibi tat değiştirici ajanların ilavesi yapılarak elemeyi denemek yerine, rahatsız edici tadı değiştirmek, modüle etmek veya maskelemek olmuştur (Stepaniak, 2004; Chakrabarti vd., 2018). Ac1 tadın maskelenmesine katkıda bulunan yöntemlerden biri deaminasyon işlemidir. Bu işlem ile spesifik enzimler tarafindan amino gruplar1 uzaklaştırılmakta ve umami tat veren peptitlerin artış1 söz konusu olmaktadır (Chakrabarti vd., 2018). Biyo-bazlı yöntemler arasında ise, özellikle aminopeptidazlar ve karboksipeptidazları kapsayan proteolitik enzimler ve ac1 peptitlerin hidrolizini gerçekleştirerek ac1 peptitlerin kısaltılmasını sağlayan proteinazlar içermektedir (Saha ve Hayashi, 2001). Peynirin olgunlaşma süresini kısaltmak ve acilık ile doku kusurlarını önlemek için, kademeli bir enzim salınımı gereklidir. Peynir matrisinde lipozom içeriğinin kademeli olarak serbest birakılmas1, serbest enzimlerin neden olduğu acıllğın önüne geçebilmektedir (Mohammadi vd., 2015).

Süt ürünlerindeki acılık, starter veya yardımc1 mikrofloranın seçilmesiyle giderilebilmekte veya kontrol edilebilmektedir (Stepaniak, 2004). Laktik asit bakterilerinin çoğunda ekzopeptidaz aktivitenin tespit edilmiş ve bu mikroorganizmalar acı tadın giderilmesiyle ilişkilendirilmiştir (Widyastuti vd., 2014). Lactobacillus bulgaricus peynirde dipeptidaz aktivitesinin artışın sağlamakta ve bu aktiviteye bağlı olarak acı peptitlerin parçalanması sağlanmaktadır. $\mathrm{Bu}$ nedenle Cheddar peyniri ve diğer peynirlerde acı tadı azaltmak için mezofilik starterler ile Lactobacillus bulgaricus yardımc1 kültür olarak eklenebilmektedir (Teixeria, 2014). Baz1 Lactobacillus spp. türleri, özellikle $L b$. casei, güçlü bir acılık giderme aktivitesindeki enzim sistemine sahip olan starter olmayan mikroorganizmalardır. Ayrica Pseudomonas fluorescens'ten gelen proteinaz ve aminopeptidaz da acillk giderme aktivitesi gösterdiği belirtilmektedir (Stepaniak, 2004). Camembert tipi küflü peynirlerin olgunlaşması sirasinda Penicillium camemberti ve Geotrichum candidum sinerjistik bir proteolitik aktivite göstermektedir. $P$. camemberti, ac1 tat veren hidrofobik peptitler üretme eğilimindedir, ancak G. candidum'un aminopeptidazlar1 ile bu peptitler hidrolize uğramakta ve ac1 tat azalabilmektedir (Desmasures, 2014; Grygier vd., 2017; Krisch vd., 2015). Proline özgü endo ve ekzopeptidazlar, peynirin olgunlaştırılmasında ya da acilı̆ı̆n giderilmesinde ya prolin içeren genellikle acı olan peptitlerin parçalanması ya da prolin çıkarılarak peptitlerin diğer peptidazların etkisine erişilebilir olmasını sağlaması ile önemli rol oynamaktadır. Prolin içeren dipeptitler acı tat vermektedir. PepN, PepP ve PepX tipleri olan aminopeptidazlar ve karboksipeptidazlar süt proteini hidrolizatları, peynirler ve enzimle modifiye edilmiş peynirler için etkili bir acılık giderme maddesi olarak kabul edilmektedir (Stepaniak, 2004). Üretim aşamasında uygulanan işlemler de ürünün acı tadı üzerinde etki göstermektedir. Isıtma ve dondurma/çözündürme işlemleri Lactobacillus belveticus CNRZ 32'un hücre içi peptidazlarının hızlı bir şekilde salınımına yol açar ve böylece peynir ortamına geçen bu enzimler acı peptitlerin giderilmesinde katkıda bulunabilmektedir (Yarlagadda, 2014).

Hücre dış1 proteinaz acı tattaki $a_{51}$-kazein f1-9 ve $\beta$-kazein f193-209'i, hücre içi aminopeptidaz ise 
sentetik ac1 peptitleri degradasyona uğratabilmektedir (Stepaniak, 2004; Yarlagadda, 2014; Widyastuti vd., 2014). Peynir olgunlaşması sirasinda, peptidazlar sekonder proteolizden, yani plazmin veya kimozin tarafindan açığa çıkan peptitlerin parçalanmasından, acılık gidermeden ve serbest amino asitlerin üretilmesinden sorumlu tutulmaktadır (Stepaniak, 2004). Sığır pankreasindan elde edilen bir ekzopeptidaz olan karboksipeptidaz A, peptit zincirinin C-terminal uçlarındaki hidrofobik amino asitleri uzaklaştırarak acılığı giderebilmektedir. Bu enzim, protein bileşenleri hidrofobik amino asitler bakımından zengin olan süt endüstrisinde, acıllı̆̆ı giderilmesinde önem arz etmektedir (Cacicedo vd., 2019). Peynir üretiminde kullanılan deve kimozininin $a$-ve $\beta$-kazeinleri hidrolize edebilmesi ve $a_{\mathrm{s} 1}$-kazeindeki Leu ${ }_{192}-\mathrm{Tyr}_{193}$ bağını parçalaması ve $\beta$-kazein kaynaklı f193-209 fragmanını açığa çıkarması sonucu peynirde acı tat oluşumu söz konusu olabilmektedir. Ancak süt pihtılaşma aktivitesinin genel proteolitik aktiviteye oran1 bakımından deve kimozininin sığır kimozinine göre daha yüksek olduğu belirtilmiştir. Böylece peynir üretiminde daha düşük dozda deve kimozini kullanımı mümkün olabilmektedir. Deve kimozininin kullanımıla daha sert yapıda ve daha az acıllkta peynirlerin üretildiği saptanmıstır. Bu nedenle ac1 tat kusuru meydana gelmeden peynir üretimi için sığır kimozini yerine deve kimozininin kullanımı önerilmiştir (Ghnimi ve Kamal-Eldin, 2015; Børsting vd., 2014). Ayrica sprey kurutma yoluyla peynir altı suyu protein hidrolizatının sodyum aljinat karışımıla mikrokapsüllemesi ile acilğ̆ın giderilmesi mümkün olabilmektedir (Ma vd., 2014). Favaro-Trindade vd. (2010), püskürtmeli kurutma işleminin peptitlerin sudaki çözünürlüklerini düşürücü etkide bulunduğunu ve bu durumun da acı tadın maskelenmesine neden olduğunu belirtmiştir. Son zamanlarda yapılan bir araştırma, sığır proteini hidrolizatlanından spesifik peptitlerin ac1 tat reseptörü T2R4'ü bloke edebileceğini ve sadece acıyı maskelemek yerine ac1 tat algisını doğrudan engelleyebildiğini göstermiştir (Chakrabarti vd., 2018).

\section{SÜT ÜRÜNLERİNDE YAPILAN GÜNCEL ACI PEPTİT ÇALIŞMALARI}

Acılık, dilin arkasına doğru algilanan bir tat hissidir ve peynir, fermente sütler ve kazein hidrolizatları dahil süt ürünleri ile ilişkili bir tat kusurudur. Peynirdeki birçok bileşik, acı bir tada sahip olmasına rağmen peynirdeki acı tat kusurunun, aşırı hidrofobik peptitlerin birikmesinden kaynaklandığ1 düşünülmektedir. Süt ürünlerinde tanımlanan peptitler ve bu peptitlere ilişkin bazı özellikler Çizelge 1'de verilmiştir. Bir peptitin acıllı̆̆, ortalama hidrofobisiteye bağlı olduğu gibi hidrofobik amino asit kalıntılarının peptit zinciri boyunca dağılımına da bağlıdır. Kazeinlerin, nispeten hidrofobik proteinler oldukları göz önüne alındığında bu durum peynir için önem arz etmektedir. Ac1lik, genellikle k1sa zincirli hidrofobik peptitler ile ilişkilendirilmektedir. Nispeten hidrofobik olsalar bile, daha büyük peptitler aynı hidrofibisite değerindeki kısa bir peptitten daha az ac1 olarak algilanmaktadır. Ayrica ekzopeptidazların etkisiyle kisa zincirli peptitin amino asitlerine parçalanması ac1 şiddetini azaltmaktadır (McSweeney, 2007; Briand ve Salles; 2016). Peynirdeki ac1 tat kusuru, hidrofobik kısa peptitlerin ya aşırı üretimi ya da peptidaz aktivitesinin yetersizliğinden dolayı yeterli degradasyon olmaması sonucu yüksek konsantrasyonda birikmesi nedeniyle ortaya çıkmaktadır (McSweeney, 2007). Starter kültürlerin süt üretimindeki önemli rollerinden biri, pıhtılaştırıcı tarafindan üretilen peptitleri, küçük peptitlere ve amino asitlere parçalamasıdır. Bununla birlikte, proteolitik enzimlerin birçoğu hücre içi pozisyonda olduğundan, starter kültürlerin hücrelerinin lize uğraması ile peynir matriksine özellikle peptidazların ve amino asit parçalayan enzimlerden oluşan hücre içi enzimlerin salınımı söz konusu olmakta ve bu durum hem protein degradasyonu hem de acilığın kontrolü için önem arz etmektedir (Thierry vd., 2015; Altieri vd., 2017). 
Çizelge 1. Süt ürünlerinde belirlenen acı peptitler

\begin{tabular}{|c|c|c|c|c|c|}
\hline İzole edildiği kaynak & $\begin{array}{l}\text { Ac1 peptit } \\
\text { kaynağ1 }\end{array}$ & Pozisyonu & Dizilimi & $\begin{array}{l}\text { Hidrofobisite } \\
\text { (cal/res) }\end{array}$ & Referans \\
\hline Cheddar peyniri & $a_{\mathrm{s} 1}-$ kazein & f1-7 & Arg-Pro-Lys-His-Pro-Ile-Lys & 1771.0 & Lee vd., 1996 \\
\hline Cheddar peyniri & $a_{\mathrm{s} 1}$-kazein & f1-9 & $\begin{array}{l}\text { Arg-Pro-Lys-His-Pro-Ile-Lys- } \\
\text { His-Gln }\end{array}$ & & $\begin{array}{l}\text { Broadbent } \\
\text { vd., } 2002\end{array}$ \\
\hline Cheddar peyniri & $a_{\mathrm{s} 1}$-kazein & $\mathrm{f} 1-13$ & $\begin{array}{l}\text { Arg-Pro-Lys-His-Pro-Ile-Lys- } \\
\text { His-Gln-Gly-Leu-Pro-Gln }\end{array}$ & 1363.0 & Lee vd., 1996 \\
\hline Cheddar peyniri & $a_{\mathrm{s} 1}$-kazein & f11-14 & Leu-Pro-Gln-Glu & 1367.0 & Lee vd., 1996 \\
\hline Cheddar peyniri & $a_{\mathrm{s} 1}$-kazein & f14-17 & Glu-Val-Leu-Asn & 1162.5 & $\begin{array}{l}\text { Lemieux ve } \\
\text { Simard, } 1992\end{array}$ \\
\hline Cheddar peyniri & $a_{\mathrm{s} 1}-\mathrm{kazein}$ & f17-21 & Asn-Glu-Asn-Leu-Leu & 1074.0 & $\begin{array}{l}\text { Lemieux ve } \\
\text { Simard, } 1992\end{array}$ \\
\hline Cheddar peyniri & $a_{\mathrm{s} 1}$-kazein & f26-32 & Ala-Pro-Phe-Pro-Glu-Val-Phe & 1930.0 & $\begin{array}{l}\text { Lemieux ve } \\
\text { Simard, } 1992\end{array}$ \\
\hline Cheddar peyniri & $a_{\mathrm{s} 1}$-kazein & f26-33 & $\begin{array}{l}\text { Ala-Pro-Phe-Pro-Glu-Val- } \\
\text { Phe-Gly }\end{array}$ & 1688.75 & $\begin{array}{l}\text { Lemieux ve } \\
\text { Simard, } 1992\end{array}$ \\
\hline Cheddar peyniri & $a_{\mathrm{s} 1}$-kazein & f94-100 & $\begin{array}{l}\text { Tyr-Leu-Glu-Gln-Leu-Leu- } \\
\text { Arg }\end{array}$ & 1615.7 & $\begin{array}{l}\text { Lemieux ve } \\
\text { Simard, } 1992\end{array}$ \\
\hline Cheddar peyniri & $a_{\mathrm{s} 2}$-kazein & f191-197 & Lys-Pro-Trp-Ile-Gln-Pro-Lys & 2010.0 & Lee vd., 1996 \\
\hline Cheddar peyniri & $\beta$-casein & f8-16 & $\begin{array}{l}\text { Val-Pro-Gly-Glu-Ile-Val-Glu- } \\
\text { Ser-Leu }\end{array}$ & 1390.0 & Lee vd., 1996 \\
\hline Cheddar peyniri & $\beta$-casein & f46-65 & $\begin{array}{l}\text { Gln-Asp-Lys-Ile-His-Pro-Phe- } \\
\text { Ala-Gln-Thr-Gln-Ser-Leu- } \\
\text { Val-Tyr-Pro-Phe-Pro-Gly-Pro }\end{array}$ & 1459.0 & $\begin{array}{l}\text { Lemieux ve } \\
\text { Simard, } 1992\end{array}$ \\
\hline Cheddar peyniri & $\beta$-casein & f46-67 & $\begin{array}{l}\text { Gln-Asp-Lys-Ile-His-Pro-Phe- } \\
\text { Ala-Gln-Thr-Gln-Ser-Leu-Val- } \\
\text { Tyr-Pro-Phe-Pro-Gly-Pro-Ile- } \\
\text { Pro }\end{array}$ & 1580.45 & $\begin{array}{l}\text { Lemieux ve } \\
\text { Simard, } 1992\end{array}$ \\
\hline Cheddar peyniri & $\beta$-casein & f46-84 & $\begin{array}{l}\text { Gln-Asp-Lys-lle-His-Pro-Phe- } \\
\text { Ala-Gln-Thr-Gln-Ser-Leu-Val- } \\
\text { Tyr-Pro-Phe-Pro-Gly-Pro-Ile- } \\
\text { Pro-Asn-Ser-Leu-Pro-Gln- } \\
\text { Asn-lle-Pro-Pro-Leu-Thr-Gln- } \\
\text { Thr-Pro-Val-Val-Val }\end{array}$ & 1508.5 & $\begin{array}{l}\text { Lemieux ve } \\
\text { Simard, } 1992\end{array}$ \\
\hline Cheddar peyniri & $\beta$-casein & f102-119 & $\begin{array}{l}\text { Met-Ala-Pro-Lys-His-Lys-Glu- } \\
\text { Met-Pro-Phe-Pro-Lys-Tyr- } \\
\text { Pro-Val-Glu-Pro-Phe }\end{array}$ & & $\begin{array}{l}\text { Karametsi vd., } \\
2014\end{array}$ \\
\hline Cheddar peyniri & $\beta$-casein & f103-119 & $\begin{array}{l}\text { Ala-Pro-His-Gly-Lys-Glu- } \\
\text { Met-Pro-Phe-Pro-Lys-Tyr- } \\
\text { Pro-Val-Glu-Pro-Phe }\end{array}$ & & $\begin{array}{l}\text { Karametsi vd., } \\
2014\end{array}$ \\
\hline Cheddar peyniri & $\beta$-casein & f109-119 & $\begin{array}{l}\text { Met-Pro-Phe-Pro-Lys-Tyr- } \\
\text { Pro-Val-Glu-Pro-Phe }\end{array}$ & & $\begin{array}{l}\text { Karametsi vd., } \\
2014\end{array}$ \\
\hline Cheddar peyniri & $\beta$-casein & f193-207 & $\begin{array}{l}\text { Tyr-Gln-Glu-Pro-Val-Leu- } \\
\text { Gly-Pro-Val-Arg-Gly-Pro- } \\
\text { Phe-Pro-Ile }\end{array}$ & & $\begin{array}{l}\text { Karametsi vd., } \\
2014\end{array}$ \\
\hline Cheddar peyniri & $\beta$-casein & f193-209 & $\begin{array}{l}\text { Tyr-Gln-Gln-Pro-Val-Leu- } \\
\text { Gly-Pro-Val-Arg-Gly-Pro- } \\
\text { Phe-Pro-Ile-Ile-Val }\end{array}$ & & $\begin{array}{l}\text { Broadbent } \\
\text { vd., } 2002\end{array}$ \\
\hline Cheddar peyniri & $\beta$-casein & f199-209 & $\begin{array}{l}\text { Gly-Pro-Val-Arg-Gly-Pro- } \\
\text { Phe-Pro-Ile-Ile-Val }\end{array}$ & & $\begin{array}{l}\text { Karametsi vd., } \\
2014\end{array}$ \\
\hline
\end{tabular}


Çizelge 1. devam

\begin{tabular}{|c|c|c|c|c|c|}
\hline İzole edildiği kaynak & $\begin{array}{l}\text { Ac1 peptit } \\
\text { kaynağ1 }\end{array}$ & Pozisyonu & Dizilimi & $\begin{array}{l}\text { Hidrofobisite } \\
\text { (cal/res) }\end{array}$ & Referans \\
\hline Gouda & $\beta$-casein & f58-68 & $\begin{array}{l}\text { Leu-Val-Tyr-Pro-Phe-Pro- } \\
\text { Gly-Pro-Ile-His-Asn }\end{array}$ & 1905.0 & $\begin{array}{l}\text { Toelstede ve } \\
\text { Hofmann, } \\
2008\end{array}$ \\
\hline Gouda & $\beta$-casein & f60-69 & $\begin{array}{l}\text { Tyr-Pro-Phe-Pro-Gly-Pro-Ile- } \\
\text { His-Asn-Ser }\end{array}$ & 1688.0 & $\begin{array}{l}\text { Toelstede ve } \\
\text { Hofmann, } \\
2008\end{array}$ \\
\hline Gouda & $\beta$-casein & f $60-68$ & $\begin{array}{l}\text { Tyr-Pro-Phe-Pro-Gly-Pro-Ile- } \\
\text { His-Asn }\end{array}$ & 1871.0 & $\begin{array}{l}\text { Toelstede ve } \\
\text { Hofmann, } \\
2008\end{array}$ \\
\hline Gouda & $\beta$-casein & f84-89 & Val-Pro-Pro-Phe-Leu-Gln & 1983.3 & $\begin{array}{l}\text { Lemieux ve } \\
\text { Simard, } 1992\end{array}$ \\
\hline Gouda & $\beta$-casein & f193-207 & $\begin{array}{l}\text { Tyr-Gln-Gln-Pro-Val-Leu- } \\
\text { Gly-Pro-Val-Arg-Gly-Pro- } \\
\text { Phe-Pro-Ile }\end{array}$ & 1686.7 & $\begin{array}{l}\text { Lemieux ve } \\
\text { Simard, } 1992\end{array}$ \\
\hline Gouda & $\beta$-casein & f193-208 & $\begin{array}{l}\text { Tyr-Gln-Gln-Pro-Val-Leu- } \\
\text { Gly-Pro-Val-Arg-Gly-Pro- } \\
\text { Phe-Pro-Ile-Ile }\end{array}$ & 1766.9 & $\begin{array}{l}\text { Lemieux ve } \\
\text { Simard, } 1992\end{array}$ \\
\hline Gouda & $\beta$-casein & f193-209 & $\begin{array}{l}\text { Tyr-Gln-Gln-Pro-Val-Leu- } \\
\text { Gly-Pro-Val-Arg-Gly-Pro- } \\
\text { Phe-Pro-Ile-Ile-Val }\end{array}$ & 1762.4 & $\begin{array}{l}\text { Lemieux ve } \\
\text { Simard, } 1992\end{array}$ \\
\hline Gouda & $\beta$-casein & f193-209 & $\begin{array}{l}\text { Tyr-Gln-Gln-Pro-Val-Leu- } \\
\text { Gly-Pro-Val-Arg-Gly-Pro- } \\
\text { Phe-Pro-Ile-Ile-Val }\end{array}$ & 1762.0 & $\begin{array}{l}\text { Toelstede ve } \\
\text { Hofmann, } \\
2008\end{array}$ \\
\hline Gouda & & & $\begin{array}{l}\text { Tyr-Pro-Phe-Pro-Gly-Pro-Ile- } \\
\text { Pro-Asn-Ser }\end{array}$ & 1900.0 & $\begin{array}{l}\text { Toelstede ve } \\
\text { Hofmann, } \\
2008\end{array}$ \\
\hline $\begin{array}{l}\text { Alpkäse (İsviçre dağ } \\
\text { peyniri) }\end{array}$ & $a_{\mathrm{s} 1}$-kazein & f198-199 & Leu-Trp & 2710.0 & $\begin{array}{l}\text { Lemieux ve } \\
\text { Simard, } 1992\end{array}$ \\
\hline Butterkäse & $\beta$-casein & f61-69 & $\begin{array}{l}\text { Pro-Phe-Pro-Gly-Pro-Ile-Pro- } \\
\text { Asn-Ser }\end{array}$ & 1792.2 & $\begin{array}{l}\text { Lemieux ve } \\
\text { Simard, } 1992\end{array}$ \\
\hline $\begin{array}{l}\text { Kazein } \\
\text { hidrolizatı/Peynir } \\
\text { mayası }\end{array}$ & $a_{\mathrm{s} 1}$-kazein & f19-32 & Pro-Gln-Val·Phe & 1715.0 & $\begin{array}{l}\text { Lemieux ve } \\
\text { Simard, } 1992\end{array}$ \\
\hline $\begin{array}{l}\text { Kazein } \\
\text { hidrolizatı/Peynir } \\
\text { mayası }\end{array}$ & $a_{\mathrm{s} 1}$-kazein & f21-23 & Leu-Arg-Phe & 1933.3 & $\begin{array}{l}\text { Lemieux ve } \\
\text { Simard, } 1992\end{array}$ \\
\hline $\begin{array}{l}\text { Kazein } \\
\text { hidrolizatı/Peynir } \\
\text { mayası }\end{array}$ & $a_{\mathrm{s} 1}$-kazein & f92-99 & $\begin{array}{l}\text { Leu-Gly- } \quad \text { Tyr-Leu-Glu-Gln- } \\
\text { Leu-Leu }\end{array}$ & 1625.0 & $\begin{array}{l}\text { Lemieux ve } \\
\text { Simard, } 1992\end{array}$ \\
\hline $\begin{array}{l}\text { Kazein } \\
\text { hidrolizatı/Peynir } \\
\text { mayası }\end{array}$ & $a_{\mathrm{s} 1}$-kazein & f99-101 & Leu-Arg-Leu & 1856.7 & $\begin{array}{l}\text { Lemieux ve } \\
\text { Simard, } 1992\end{array}$ \\
\hline $\begin{array}{l}\text { Kazein } \\
\text { hidrolizat1/Peynir } \\
\text { mayası }\end{array}$ & $a_{\mathrm{s} 1}$-kazein & f143-149 & Ala-Tyr-Phe-Tyr-Pro-G1u-Leu & 2101.4 & $\begin{array}{l}\text { Lemieux ve } \\
\text { Simard, } 1992\end{array}$ \\
\hline $\begin{array}{l}\text { Kazein } \\
\text { hidrolizatı/Peynir } \\
\text { mayası }\end{array}$ & $a_{\mathrm{s} 1}$-kazein & f167-179 & $\begin{array}{l}\text { Val-Pro-Leu-Gly-Thr-Gln- } \\
\text { Tyr-Thr -Asp-Ala-Pro-Ser-Phe }\end{array}$ & 1304.6 & $\begin{array}{l}\text { Lemieux ve } \\
\text { Simard, } 1992\end{array}$ \\
\hline $\begin{array}{l}\text { Kazein } \\
\text { hidrolizat1/Peynir } \\
\text { mayası }\end{array}$ & $\beta$-casein & f103-105 & Ala-Pro-Lys & 1616.7 & $\begin{array}{l}\text { Lemieux ve } \\
\text { Simard, } 1992\end{array}$ \\
\hline
\end{tabular}


Çizelge 1. devam

\begin{tabular}{|c|c|c|c|c|c|}
\hline İzole edildiği kaynak & $\begin{array}{l}\text { Ac1 peptit } \\
\text { kaynağı }\end{array}$ & Pozisyonu & Dizilimi & $\begin{array}{c}\text { Hidrofobisite } \\
\text { (cal/res) }\end{array}$ & Referans \\
\hline $\begin{array}{l}\text { Kazein } \\
\text { hidrolizatı/Peynir } \\
\text { mayası }\end{array}$ & $\beta$-casein & f128-139 & $\begin{array}{l}\text { Thr-Asp- Val-Glu-Asn-Leu- } \\
\text { His-Leu-Pro-Pro-Leu-Leu }\end{array}$ & 1552.5 & $\begin{array}{l}\text { Lemieux ve } \\
\text { Simard, } 1992\end{array}$ \\
\hline $\begin{array}{l}\text { Kazein } \\
\text { hidrolizat1/Peynir } \\
\text { mayas1 }\end{array}$ & $\beta$-casein & f190-192 & Phe-Leu-Leu & 2496.7 & $\begin{array}{l}\text { Lemieux ve } \\
\text { Simard, } 1992\end{array}$ \\
\hline $\begin{array}{l}\text { Kazein } \\
\text { hidrolizat1/Peynir } \\
\text { mayas1 }\end{array}$ & $\beta$-casein & f203-208 & Gly-Pro-Phe-Pro-Ile-Ile & 2305.0 & $\begin{array}{l}\text { Lemieux ve } \\
\text { Simard, } 1992\end{array}$ \\
\hline $\begin{array}{l}\text { Kazein } \\
\text { hidrolizat1/Peynir } \\
\text { mayast-Tripsin }\end{array}$ & $\beta$-casein & f203-209 & Gly-Pro-Phe-Pro-Ile-Ile-Val & 2217.1 & $\begin{array}{l}\text { Lemieux ve } \\
\text { Simard, } 1992\end{array}$ \\
\hline $\begin{array}{l}\text { Kazein } \\
\text { hidrolizat1/Tripsin }\end{array}$ & $a_{\mathrm{s} 1}$-kazein & f23-34 & $\begin{array}{l}\text { Phe-Phe-Val-Ala-Pro-Phe- } \\
\text { Pro-Glu-Val-Phe-Gly-Lys }\end{array}$ & 1833.3 & $\begin{array}{l}\text { Lemieux ve } \\
\text { Simard, } 1992\end{array}$ \\
\hline $\begin{array}{l}\text { Kazein } \\
\text { hidrolizatı/Tripsin }\end{array}$ & $a_{s 1}$-kazein & f91-100 & $\begin{array}{l}\text { Tyr-Leu-Gly-Tyr-Leu-Glu- } \\
\text { Gln-Leu-Leu-Arg }\end{array}$ & 1660.0 & $\begin{array}{l}\text { Lemieux ve } \\
\text { Simard, } 1992\end{array}$ \\
\hline $\begin{array}{l}\text { Kazein } \\
\text { hidrolizatı/Tripsin }\end{array}$ & $a_{\mathrm{s} 1}$-kazein & f95-99 & Leu-Glu-Gln-Leu-Leu & 1542.0 & $\begin{array}{l}\text { Lemieux ve } \\
\text { Simard, } 1992\end{array}$ \\
\hline $\begin{array}{l}\text { Kazein } \\
\text { hidrolizatı/Tripsin }\end{array}$ & $a_{\mathrm{s} 1}$-kazein & f145-151 & $\begin{array}{l}\text { Phe-Tyr-Pro-Glu-Leu-Phe- } \\
\text { Arg }\end{array}$ & 2070.0 & $\begin{array}{l}\text { Lemieux ve } \\
\text { Simard, } 1992\end{array}$ \\
\hline $\begin{array}{l}\text { Kazein } \\
\text { hidrolizatı/Tripsin }\end{array}$ & $a_{\mathrm{s} 2}$-kazein & f174-181 & $\begin{array}{l}\text { Phe-Ala-Leu-Pro-Gln-Tyr- } \\
\text { Leu-Lys }\end{array}$ & 1888.75 & $\begin{array}{l}\text { Lemieux ve } \\
\text { Simard, } 1992\end{array}$ \\
\hline $\begin{array}{l}\text { Kazein } \\
\text { hidrolizatı/Tripsin }\end{array}$ & $\beta$-casein & f49-68 & $\begin{array}{l}\text { Ile-His-Pro-Phe-Ala-Gln-Thr- } \\
\text { Gln-Ser-Leu-Val-Tyr-Pro-Phe- } \\
\text { Pro-Gly-Pro-Ile-Pro-Asn }\end{array}$ & $1.61-1.53^{*}$ & $\begin{array}{l}\text { Bumberger ve } \\
\text { Belitz, } 1993\end{array}$ \\
\hline $\begin{array}{l}\text { Kazein } \\
\text { hidrolizat1/Tripsin }\end{array}$ & $\beta$-casein & f49-97 & $\begin{array}{l}\text { Ile-His-Pro-Phe-Ala-Gln-Thr- } \\
\text { Gln-Ser-Leu-Val-Tyr-Pro-Phe- } \\
\text { Pro-Gly-Pro-Ile-Pro-Asn-Ser- } \\
\text { Leu-Pro-Gln-Asn-Ile-Pro-Pro- } \\
\text { Leu-Thr-Gln-Thr-Pro-Val- } \\
\text { Val-Val-Pro-Pro-Phe-Leu- } \\
\text { Gln-Pro-Glu-Val-Met-Gly- } \\
\text { Val-Ser-Lys }\end{array}$ & $1.57-1.43^{*}$ & $\begin{array}{l}\text { Bumberger ve } \\
\text { Belitz, } 1993\end{array}$ \\
\hline $\begin{array}{l}\text { Kazein } \\
\text { hidrolizat1/Tripsin }\end{array}$ & $\beta$-casein & f191-202 & $\begin{array}{l}\text { Leu-Leu-Tyr-Gln-Gln-Pro- } \\
\text { Val-Leu-Gly-Pro-Val-Arg }\end{array}$ & $1.60-1.40^{*}$ & $\begin{array}{l}\text { Bumberger ve } \\
\text { Belitz, } 1993\end{array}$ \\
\hline & $\beta$-casein & f203-209 & Gly-Pro-Phe-Pro-Ile-Ile-Val & $2.15-2.21^{*}$ & $\begin{array}{l}\text { Bumberger ve } \\
\text { Belitz, } 1993\end{array}$ \\
\hline $\begin{array}{l}\text { Kazein } \\
\text { hidrolizat1/Kimotri } \\
\text { psin }\end{array}$ & $a_{\mathrm{s} 1}$-kazein & f145-148 & Phe-Tyr-Pro-Glu & 2172.5 & $\begin{array}{l}\text { Lemieux ve } \\
\text { Simard, } 1992\end{array}$ \\
\hline $\begin{array}{l}\text { Kazein } \\
\text { hidrolizatı/Kimotri } \\
\text { psin }\end{array}$ & $a_{\mathrm{s} 1}$-kazein & f145-150 & Phe-Tyr-Pro-Glu-Leu-Phe & 2293.3 & $\begin{array}{l}\text { Lemieux ve } \\
\text { Simard, } 1992\end{array}$ \\
\hline $\begin{array}{l}\text { Kazein } \\
\text { hidrolizat1/Kimotri } \\
\text { psin }\end{array}$ & $a_{\mathrm{s} 1}$-kazein & f149-150 & Leu-Phe & 2535.0 & $\begin{array}{l}\text { Lemieux ve } \\
\text { Simard, } 1992\end{array}$ \\
\hline $\begin{array}{l}\text { Kazein } \\
\text { hidrolizatı/Kimotri } \\
\text { psin }\end{array}$ & $a_{\mathrm{s} 2}$-kazein & & $\begin{array}{l}\text { Val-Glu-Val-Phe-Ala-Pro-Pro- } \\
\text { Phe }\end{array}$ & 1900.0 & $\begin{array}{l}\text { Lemieux ve } \\
\text { Simard, } 1992\end{array}$ \\
\hline
\end{tabular}


Çizelge 1. devam

\begin{tabular}{|c|c|c|c|c|c|}
\hline İzole edildiği kaynak & $\begin{array}{l}\text { Ac1 peptit } \\
\text { kaynağ1 }\end{array}$ & Pozisyonu & Dizilimi & $\begin{array}{l}\text { Hidrofobisite } \\
\text { (cal/res) }\end{array}$ & Referans \\
\hline $\begin{array}{l}\text { Kazein } \\
\text { hidrolizatı/Mikrobi } \\
\text { yal proteinaz }\end{array}$ & $a_{\mathrm{s} 2}$-kazein & & $\begin{array}{l}\text { Leu-Val-Pro-Arg-Tyr-Phe- } \\
\text { Gly--- }\end{array}$ & & $\begin{array}{l}\text { Lemieux ve } \\
\text { Simard, } 1992\end{array}$ \\
\hline $\begin{array}{l}\text { Kazein } \\
\text { hidrolizatı/Mikrobi } \\
\text { yal proteinaz }\end{array}$ & $a_{\mathrm{s} 2}$-kazein & & $\begin{array}{l}\text { Val-Tyr-Pro-Phe-Pro-Pro-Gly- } \\
\text { Ile-Asn-His }\end{array}$ & 1853.0 & $\begin{array}{l}\text { Lemieux ve } \\
\text { Simard, } 1992\end{array}$ \\
\hline $\begin{array}{l}\text { Kazein } \\
\text { hidrolizatı/Mikrobi } \\
\text { yal proteinaz }\end{array}$ & $\beta$-casein & f167-175 & $\begin{array}{l}\text { Gln-Ser-Lys-Val-Leu-Pro-Val- } \\
\text { Pro-Gln }\end{array}$ & 1375.6 & $\begin{array}{l}\text { Lemieux ve } \\
\text { Simard, } 1992\end{array}$ \\
\hline $\begin{array}{l}\text { Kazein } \\
\text { hidrolizatı/Mikrobi } \\
\text { yal proteinaz }\end{array}$ & $\beta$-casein & f176-182 & Lys-Ala-Val-Pro-Tyr-Pro-Gln & 1704.3 & $\begin{array}{l}\text { Lemieux ve } \\
\text { Simard, } 1992\end{array}$ \\
\hline $\begin{array}{l}\text { Kazein } \\
\text { hidrolizatı/Mikrobi } \\
\text { yal proteinaz }\end{array}$ & $\beta$-casein & f183-193 & $\begin{array}{l}\text { Arg-Asp-Met-Pro-Ile-Gln-Ala- } \\
\text { Phe-Leu-Leu- Tyr }\end{array}$ & 1740.9 & $\begin{array}{l}\text { Lemieux ve } \\
\text { Simard, } 1992\end{array}$ \\
\hline $\begin{array}{l}\text { Kazein } \\
\text { hidrolizatı/Mikrobi } \\
\text { yal proteinaz }\end{array}$ & $\beta$-casein & f194-207 & $\begin{array}{l}\text { Gln-Gln-Pro-Val-Leu-Gly- } \\
\text { Pro-Val-Arg-Gly-Pro-Phe- } \\
\text { Pro-Ile }\end{array}$ & 1602.1 & $\begin{array}{l}\text { Lemieux ve } \\
\text { Simard, } 1992\end{array}$ \\
\hline $\begin{array}{l}\text { Kazein } \\
\text { hidrolizatt/Mikrobi } \\
\text { val proteinaz }\end{array}$ & $\beta$-casein & f202-209 & $\begin{array}{l}\text { Arg-Gly-Pro-Phe-Pro-Ile-Ile- } \\
\text { Val }\end{array}$ & 2031.25 & $\begin{array}{l}\text { Lemieux ve } \\
\text { Simard, } 1992\end{array}$ \\
\hline $\begin{array}{l}\text { Kazein } \\
\text { hidrolizatı/Papain }\end{array}$ & $\beta$-casein & f53-79 & $\begin{array}{l}\text { Ala-Gln-Thr-Gm-Ser-Leu-Val- } \\
\text { Tyr-Pro-Phe-Pro-Gly-Pro-Ile- } \\
\text { Pro-Asn-Ser-LeuPro-Gln-Asn- } \\
\text { Ile-Pro-Pro-Leu-Thr-Gln }\end{array}$ & & $\begin{array}{l}\text { Clegg } \\
1974\end{array}$ \\
\hline $\begin{array}{l}\text { Kazein } \\
\text { hidrolizatı/Pronaz }\end{array}$ & $a_{\mathrm{s} 2}$-kazein & & Glu $_{2}, \mathrm{Pro}_{3}, \mathrm{Val}_{1}, \mathrm{Leu}_{1}, \mathrm{Tyr}_{4}, \mathrm{Phe}_{1}$ & 2266.7 & $\begin{array}{l}\text { Lemieux ve } \\
\text { Simard, } 1992\end{array}$ \\
\hline $\begin{array}{l}\text { Kazein } \\
\text { hidrolizatı/Pronaz }\end{array}$ & $a_{\mathrm{s} 2}$-kazein & & $\mathrm{Glu}_{4}, \mathrm{Pro}_{2}, \mathrm{Tyr}_{2}, \mathrm{Phe}_{2}$ & 1848.0 & $\begin{array}{l}\text { Lemieux ve } \\
\text { Simard, } 1992\end{array}$ \\
\hline $\begin{array}{l}\text { Peynir altı suyu } \\
\text { proteini hidrolizat }\end{array}$ & $\begin{array}{l}\beta- \\
\text { lactoglobulin }\end{array}$ & & Tyr-Gly-Leu-Phe & & Liu vd., 2014 \\
\hline $\begin{array}{l}\text { Peynir altı suyu } \\
\text { proteini hidrolizat }\end{array}$ & $\begin{array}{l}\text { Serum } \\
\text { albumin }\end{array}$ & & Ile-Pro-Ala-Val-Phe & & Liu vd., 2014 \\
\hline $\begin{array}{l}\text { Peynir alt1 suyu } \\
\text { proteini hidrolizat }\end{array}$ & $\beta$-casein & & Leu-Leu-Phe & & Liu vd., 2014 \\
\hline
\end{tabular}

*Peptit diziliminin hidrofobisite birimi kcal/mol cinsinden belirtilmiştir.

Peptitlerin tadı yapılarına ve fizikokimyasal özelliklerine bağlıdır. Acı tattaki peptitler, çok sayıda acı tatta amino asit içermektedir. Peynirde ac1 peptitler kazein parçalanmasından meydana gelmekte ve disiklo piperazinleri olarak isimlendirilen siklik dipeptitler, lineer homologlarından daha ac1 alg1lanmaktadir (Guichard ve Salles, 2016). Ac1 bileşiklerin proteoliz yoluyla oluşumu dinamik bir işlemdir ve tek bir parametreyle yorumlanması doğru bir yaklaşım değildir. Ac1 bileșikler genellikle $\beta$ kazeinin hidrolize uğraması ile açığa çıkan 3-15 amino asit içeren hidrofobik peptitler olup süt ürünlerindeki acılık, trikloroasetik asitte çözünür azot miktarındaki artışla ilişkilendirilebilir. Ac1 peptitler genellikle izolösin, lösin, tirozin, valin, triptofan ve fenilalanin ve özellikle prolin varllğ̣ ile karakterize edilmiştir. Ayrıca, bu hidrofobik peptitlerin daha küçük peptitlere ve serbest amino asitlere esas olarak ekzopeptidaz etkisiyle hidrolize edilmesiyle fosfotungustik asitte çözünür azot miktarında artış olduğu ve acıllğın azaldığı belirtilmiştir (Bas vd., 2019).

Sütte bulunan plazmin, yoğurtta kazeinleri hidrolize ederek acı peptitlerin oluşumuna neden 
olmaktadır. Süt proteini konsantresi ile takviye edilen yoğurdun ac1lı̆ı, laktozsuz yoğurt starter bakterilerinin proteolitik aktivitesi ile bağlantılı olabilir (Jørgensen vd., 2019). Orta Doğu beslenmesine özgü süt ürünü olan Kishk yardımıla üretilen yarı sert peynirde kullanılan rennetin, starter proteinazlar tarafindan küçük ac1 peptitlere indirgenecek olan uzun peptitlerin üretiminden sorumlu olduğu ifade edilmiştir. Ayrıca bu peynirde acılık kaynağının hidrofobik peptitler ve ac1 tattan (metiyonin, fenilalanin ve lösin) sorumlu serbest amino asitleri içeren proteoliz türevli ürünler olduğu belirtilmiştir (Hajj vd, 2019).

Peynir üretiminde kullanılan tuzun işlevlerinden biri, proteinlerin acı peptitlere doğru parçalanma aktivitesini inhibe etmesidir. İsrail'de yaygin olarak üretilen taze ve yar1 sert Tzfat peyniri ile ilgili yapılan bir çalışmada sodyum içeriğini azaltmak için tuz ikame edici karışımlar kullanılmıştır. Çalışma sonunda tuz içeriği azaltılmamış ile sodyum ve potasyum karışımlarının kullanımıla toplam sodyum içeriğinin \%50'sinin azaltılması ile elde edilen peynirlerin acilıklar1 aynı seviyede bulunmuştur (Carmi ve Benjamin, 2017). Ancak başka bir çalısmada enzimatik pıhtılaşma ile elde edilen Brezilya'ya özgü ticari Prato peynirlerinde yüksek tuz konsantrasyonu ile ac1 tattaki peptit (m/z 1536, $a_{\mathrm{s} 1}$-kazein f1-13) miktar1 arasinda bir ilişski bulunmuştur. Çalışmada yüksek tuz içeriğinin Lactococcus lactis subsp. lactis ve Lactococcus lactis subsp. cremoris'in gelişimini inhibe ettiğini ve düşük hidrolizasyona bağlı olarak bu acı peptitin biriktiği kanısına varılmıştır (Baptista vd., 2017). Nuñez vd. (2020), tuz konsantrasyonunun azalmasının $\beta$-kazein (f1-189 / 192) hidrofobik ac1 peptit oluşumunun artmasına neden olduğunu belirtmiştir.

Gouda peynirindeki ac1 peptitler olarak tanımlanan birçok peptit, genellikle $\beta$-kazeinden (193-209) ve özellikle $N$-terminal $\beta$-kazein (57-69) fragmanindan kaynaklanabilmektedir. Gouda peynirindeki peptitler peynirin acılık algisinda önemli bir rol oynamaktadır. Peynir lezzetinin gelişiminde yardımcı kültürlerin etkinliği suşa özgüdür ve starter kültüre ait hücre içi enzimlerin peynir ortamına salınımında yardımcı kültür seçiminin önemli bir etkisi bulunmaktadır (Yarlagadda vd., 2014). Peynirdeki kalıntı kimozinin etkisiyle $\beta$-kazeinin Leu ${ }_{192}-\mathrm{Tyr}_{193}$ bağının parçalanmasıyla $\beta$-kazein (f193-209) peptiti oluşmaktadır. Toplam 17 amino asidin 13 'ünün hidrofobik amino asitten oluştuğu bu peptitin birikmesi olgunlaşmış peynirlerdeki acı tat ile ilişkilendirilmiştir. $\mathrm{Bu}$ peptitin $[\beta$-kazein (f193-209); m/z 1881] 60 günlük olgunlaşma sirasinda hem kontrol peynirinde hem de yardimc1 kültür olarak Lactobacillus belveticus LH-B02'nin kullanıldığ1 peynirde yüksek konsantrasyonda bulunmas1 L. helveticus'un proteolitik sisteminin bu peptitin yoğunluğunu azaltamadığ1 sonucuna varılmıştır (Baptista, 2018). Yardımcı kültür olarak Lactobacillus paracasei subsp. paracasei nin de olduğu starter kültür içeren Manchego peynirinin ticari starter kültür ile üretilen peynire göre proteoliz seviyesi daha yüksek bulunmuştur. Ancak ticari kültür kullanılmadan üretilen çiğ süt peyniri olgunlaşma sırasında daha yüksek bir proteolitik faaliyet göstermekte ve bunun bir sonucu olarak acı peptitler meydana gelmektedir. Bu nedenle çiğ süt peynirinin daha yüksek bir ac1 tat değerine sahip olduğu belirlenmiştir. Ac1 tat kusuru meydana gelmeden endüstriyel Manchego peyniri üretiminde Lactobacillus paracasei subsp. paracasei'nin yardımcı kültür olarak kullanımı mümkündür (Poveda ve Cabezas, 2015).

UHT sütte $\left(<0.2\right.$ sn için $\left.>150{ }^{\circ} \mathrm{C}\right) 20^{\circ} \mathrm{C}$ 'de 14 haftalık depolama süresince acı peptit oluşumunun gözlemlendiği bir çalışmada plazmin aktivitesine bağlı olarak $a_{\mathrm{s}^{-}}$ve $\beta$-kazein kaynaklı 23 'ü potansiyel ac1 tatta olmak üzere toplam 66 peptit tanımlanmıştır. UHT sütte acilığın büyük olasilikla $a_{\mathrm{s} 1}$ - ile $a_{\mathrm{s} 2}$-kazeinden meydana gelen peptitlerden kaynaklanabileceği belirtilmiştir (Rauh vd., 2014). Depolama koşullarının hidrolize-laktoz UHT sütünün raf ömrü üzerindeki etkisinin incelendiği bir çalışmada oda sıcaklığında yedi aylık bir depolama süresi boyunca sütte peptit ve amino asit seviyelerinin arttığ1 tespit edilmiştir. Enzimatik (laktoz hidrolizinde kullanilan enzimin proteolitik yan aktivitesi) veya enzimatik olmayan yollarla (is1 ve depolama indüksiyonu) açığa çıkan peptitlerin miktarının artmasına bağlı olarak UHT sütte zaman içinde önemli ölçüde acılık yoğunluğu 
artmıştır. Hidrofobisite değeri $1400 \mathrm{kal} / \mathrm{mol}$ den yüksek olan peptitler potansiyel olarak ac1 peptitlerdir ve bu peptitlerin miktarlar1 86 ile 116 depolama günlerinde artmıştır. Sütteki acı tadın $\beta$ kazein ve $a_{51}$-kazein hidrofobik bölgelerinden türetilmiş potansiyel ac1 peptitlerden kaynaklanabileceği ve süt proteinlerinin proteolizinin, esas olarak, kullanilan laktaz preparasyonundaki kalıntı proteolitik aktiviteden kaynaklandığı ileri sürülmektedir (Nielsen vd., 2017)

Peynirdeki enzimatik veya mikrobiyal kaynaklı kusurlar yüksek basınç uygulamaları ile kontrol edilebilmektedir (Nuñez vd., 2020). Yüksek basınç işleminin $\left(200 \mathrm{MPa}, 20{ }^{\circ} \mathrm{C}\right.$ ve 20 dakika) doğrudan salamura Beyaz peynir ya da üretimde kullanılan starter kültürü (Streptococcus thermophilus: Lactococcus lactis: Lactobacillus bulgaricus 2:1:1) üzerindeki etkisi incelendiğinde yüksek basınç uygulanmış starterlerle yapılan peynirlerde sekonder proteolizin arttığ1 tespit edilmiştir. Yüksek basınç uygulaması, ac1 tattan sorumlu bazı peptitlerin daha fazla parçalanmasına katkıda bulunan starterlerin proteolitik enzimlerini aktive edebilmekte ve bu peynirlerin aminopeptidaz aktivitelerinde artşs görülmektedir. Peynir üretiminde kullanılan starter kültürlerin yüksek basınç ile muamele edilmesi, peynirin duyusal özelliklerinin gelissimine katkıda bulunan hücre içi peptidazların aktivitesini artırarak olgunlaşmayı hızlandırabilmektedir (Giannoglou vd., 2016). Buzdolabı koşullarında depolanan ve aşırı olgunlaşmayı önlemek için $600 \mathrm{MPa}$ yüksek basınç uygulaması ile muamele edilen Brie peynirinde önemli düzeyde kalıntı kazein konsantrasyonu tespit edilmiştir. Ayrıca kontrol peynirinde 21. günden 60 . güne hidrofobik peptitlerde 7.6 kat artış ve yüksek basınç ile muamele edilmiş peynirlerde 0.8-1.6 kat artış belirlenmiştir (Calzada vd., 2014). Çĭ̆ koyun sütünden üretilen İspanyol peyniri olan Torta del Casar peynirine 5 ve 20 dakikalık $200 \mathrm{MPa}$ ile 600 $\mathrm{MPa}$ büyüklügünde basınç uygulaması sonucunda peynirlerin acılık özelliği değerlendirilmiştir. Yüksek basınç uygulanmayan kontrol peynirinin $6^{\circ} \mathrm{C}$ de olgunlaşmanın 180. gününe kiyasla 20 dakika $600 \mathrm{MPa}$ basınç uygulanan peynirlerde olgunlaşmanın 120 ve 240. günlerinde acılik puanlarının daha düşük olduğu saptanmışır (Delgado-Martínez vd., 2019).

Cheddar peynirinin ac1 tadindan sorumlu olan peptitlerin $\beta$-kazein kaynaklı olduğu belirtilen bir çalışmada beş adet GPVRGPFPIIV, YQEPVLGPVRGPFPI, MPFPKYPVEP, MAPKHKEMPFPKYPVEPF ve APHGKEMPFPKYPVEPF dizilimine sahip peptitler saptanmışır. Tanımlanan peptitlerden ilk üçünün konsantrasyonunun olgunlaşma sirasinda sirasiyla $28.7,3.1$ ve 1.8 kat arttığ1 belirtilmiştir. Cheddar peynirinin ac1 tat algisina önemli ölçüde katkıda bulunan GPVRGPFPIIV dizilimine sahip peptit olduğu bildirilmiştir (Karametsi vd., 2014). Peynir altı suyu proteini hidrolizatında ac1 peptitlerin tanımlandığı bir çalışmada $a$-laktalbumin, $\beta$-lactoglobulin, serum albumin ve $\beta$-kazein kaynaklı ac1 peptitler belirlenmiştir. $\mathrm{Bu}$ ac1 peptitlerin dizilimleri sirasiyla YGLF ( $0.66 \mathrm{~g} / \mathrm{kg}$ toz), IPAVF $(0.58 \mathrm{~g} / \mathrm{kg}$ toz), LLF (1.33 g/ kg toz) ve YPFPGPIPN (2.64 g/kg toz) olduğu saptanmıştır (Liu vd., 2014). Çiğ sütten üretilen Meksika peynirleri doğal mikroflorasının proteolize etkileri incelendiğinde hafif ac1 tat özelliğinde IPPL fragmanları içeren peptitler tespit edilmiştir (Paul vd., 2014).

Ac1 peptitler genellikle $a_{\mathrm{s} 1}$ - ve $\beta$-kazeinin hidrolize uğraması ile meydana gelse de $x$-kazein kaynaklı da oluşabilmektedir. Peynir örneklerinin peptit profilinin incelendiği bir çalışmada $\beta$-kazeinden f102-119, f169-182, f170-175, f78-91, f133-138, f133-140 ve f134-141 olmak üzere yedi adet, $x$ kazeinden öncü olarak f17-24, f43-50, f96-106, f107-131 ve f122-131 olmak üzere beş adet, $a_{\mathrm{s} 1}{ }^{-}$ kazein kaynaklı f25-35, f31-40, f56-60, f70-78 ve f81-88 olmak üzere beş adet acı peptit belirlenmiş olsa da $a_{\mathrm{s} 2}$-kazein kaynakli ac1 peptitin saptanamadığı belirtilmiştir. Çalışmada ayrıca $a_{\mathrm{s} 1}{ }^{-}$ kazein $\mathrm{f} 25-35$ peptit oluşumunun kimozin ya da katepsin D faaliyeti, $a_{\mathrm{s} 1}$-kazein f31-40, f70-78 ve f81-88 peptitlerinin oluşumunun ise sirasiyla kimozin, plazmin ve daha sonra laktokokal proteinazın faaliyeti ile meydana geldiği ifade edilmiştir. Laktokokal proteinazın faaliyeti ile $x$ kazein kaynaklı f96-106 ve f107-131 ile $\beta$-kazein f102-119, f133-138, f133-140 ve f169-182 peptitleri de açığa çıkmıştır (Sebald vd., 2018). 


\section{SONUÇ}

Tat algıs1, tat tomurcuklarının işlevini yerine getirmesine bağlı olarak oluşmaktadır. Acı tat duyusu ise tat tomurcuklarının içindeki ilgili tat reseptörlerinin uyarılması ve oluşan elektriksel sinir impulsunun sinirlerle beyne iletilmesi ile oluşmaktadır. Fonksiyonel gıdalardaki son gelişmeler, protein hidrolizatlarının üretiminin artmasına neden olmuştur. Ancak yapılan çalışmalarda pihtılaştırıcı enzimler, starter ve starter olmayan kültürler ya da süt kaynaklı enzimler tarafindan kazeinin hidrolize olması sonucu açığa çıkan hidrolizatlarda ac1 tat oluşabileceği ifade edilmiştir. Oluşan bu tat kusurunun ise nispeten kontrolsüz koşullarda üretim yapılmasından kaynaklandığı bildirilmiştir. Son yapılan çalısmalarda, biyoaktif özellik gösteren peptitlerde tüketici tercihini olumsuz etkileyen acilı̆̆n giderilmesi söz konusudur. Bunun için peptit acılı̆̆ını azaltma ya da gidermede aktif karbon uygulama, alkol ekstraksiyonu, çökeltme ve kromatografi yöntemlerinden ziyade endo ve ekzopeptidazların kullanımını içeren biyoteknolojik yöntemler tercih edilmektedir.

Süt ürünlerinde, özellikle peynir üretimi ve olgunlaşması esnasında oluşan acıllğı̆n kontrolü kültür seçimi, yardımcı kültür kullanımı, üretim koşullarının iyileştirilmesi, farklı prhtılaştırıcı ajanların kullanımı, enzimatik faaliyetlerin kontrolü ile mümkün olabilmektedir. Günümüzde, peynirde hızlı olgunlaştırma tekniklerinin uygulanmasına bağlı olarak oluşan ac1 tat kusurunun giderilmesine yönelik çalışmalar mevcuttur. $\mathrm{Bu}$ alanda araştırma faaliyetlerine devam edilmesiyle acı peptit üretmeyen kültür ve/veya kültür karışımının belirlenmesi ve protein hidrolizatlarının acılı̆̆ını giderme potansiyeli olabilecek proteaz kaynaklı plastesin gibi yeni maddelerin tespiti ve bu maddelerin kullanım olanaklarının belirlenmesi mümkün olabilir. Ayrıca ac1 peptit oluşumunun engellenemediği durumlarda ac1 tadın algilanma mekanizmasını bloke eden metabolitlerin üzerine detaylı çalışmalar da yapılabilir.

\section{KAYNAKLAR}

Altieri, C., Ciuffreda, E., Di Maggio, B., Sinigaglia, M. (2017). Lactic acid bacteria as starter cultures. In: Starter Cultures in Food Production, Speranza, B., Bevilacqua, A., Corbo, M.R., Sinigaglia, M. (eds.), $1^{\text {st }}$ Edition, John Wiley \& Sons, the UK, pp. 1-15, doi: 10.1002/9781118933794.

Aluko, R.E. (2017). Structural characteristics of food protein-derived bitter peptides. In: Bitterness: Perception, Chemistry and Food Processing, Aliani, A., Eskin, M.N.A. (eds.), $1^{\text {st }}$ Edition, The Institute of Food Technologists Press, the UK, pp. 105-129.

Aryee, A.N.A., Agyei, D., Udenigwe, C.C. (2018). Impact of processing on the chemistry and functionality of food proteins. In: Proteins in Food Processing, Yada, R.Y. (ed.), 2nd Edition, Woodhead Publishing, the UK, pp. 60-89.

Baptista, D.P., Araújo, F.D.S., Eberlin, M.N., Gigante, M.L. (2017). A survey of the peptide profile in Prato cheese as measured by MALDIMS and capillary electrophoresis. J Food Sci, 82(2): 386-393, doi: 10.1111/1750-3841.13618.

Baptista, D.P., Galli, B.D., Cavalheiro, F.G., Negrãoi, F., Eberlin, M.N., Gigante, M.L. (2018). Lactobacillus helveticus LH-B02 favours the release of bioactive peptide during Prato cheese ripening. Int Dairy J, 87: 75-83, doi: 10.1016/j.idairyj.2018.08.001.

Bas, D., Kendirci, P., Salum, P., Govce, G., Erbay, Z. (2019). Production of enzyme-modified cheese (EMC) with ripened white cheese flavour: Ieffects of proteolytic enzymes and determination of their appropriate combination. Food Bioprod Process, 117: 287-301, doi: 10.1016/j.fbp.2019.07.016.

Batu, A. (2017). Moleküler gastronomi bakış açısıyla gidaların tat ve aroma algiları. Aydin Gastron, 1(1): 25-36.

Bhopale, G.M. (2016). Bovine milk derived peptides: A comprehensive review. Eur J Pharm Med Res, 3(3): 167-170, ISSN: 3294-3211.

Børsting, M.W., Qvist, K.B., Ardö, Y. (2014). Influence of $\mathrm{pH}$ on retention of camel chymosin in curd. Int Dairy J, 38(2): 133-135, doi: 10.1016/j.idairyj.2014.01.001. 
Briand, L., Salles, C. (2016). Taste perception and integration. In: Flavor From Food to Behaviors, Wellbeing and Health, Etiévant, P., Guichard, E., Salles, C., Voilley, A. (eds.), $1^{\text {st }}$ Edition, Woodhead Publishing, the UK, pp. 101-119, ISBN-10: 0081002955.

Broadbent, J.R., Barnes, M., Brennand, C., Strickland, M., Houck, K., Johnson, M.E., Steele, J.L. (2002). Contribution of Lactococcus lactis cell envelope proteinase specificity to peptide accumulation and bitterness in reduced-fat Cheddar cheese. Appl Environ Microbiol, 68(4): 1778-1785, doi: 10.1128/AEM.68.4.17781785.2002.

Bumberger, E., Belitz, H.D. (1993). Bitter taste of enzymic hydrolysates of casein. I. Isolation, structural and sensorial analysis of peptides from tryptic hydrolysates of $\beta$-casein. Zeitschrift für Lebensmittel-Untersuchung und Forschung, 197(1): 1419, doi: 10.1007/BF01202693.

Cacicedo, M.L., Manzo, R.M., Municoy, S., Bonazza, H.L., Islan, G.A., Desimone, M., Bellino, M., Mammarella, E.J., Castro, G.R. (2019). Immobilized enzymes and their applications. In: Advances In Enayme Technology Series: Biomass, Biofuels, Biochemicals, Pandey, A. (Chief ed.), $1^{\text {st }}$ Edition, Elsevier, the UK, pp. 169200, ISBN: 978-0-444-64114-4.

Calzada, J., del Olmo, A., Picon, A., Gaya, P., Nuñez, M. (2014). Effect of high-pressureprocessing on the microbiology, proteolysis, texture and flavour of Brie cheese during ripening and refrigerated storage. Int Dairy J, 32(2): 64-73, doi: 10.1016/j.idairyj.2014.03.002.

Carmi, I.K., Benjamin, O. (2017). Reduction in sodium content of fresh, semihard Tzfat cheese using salt replacer mixtures: taste, texture and shelf life evaluation. Int J Dairy Technol, 70(3): 354364, doi: 10.1111/1471-0307.12369.

Chakrabarti, S., Guha, S., Majumder, K. (2018). Food-derived bioactive peptides in human health: Challenges and opportunities. Nutrients, 10(11): 1738; doi: 10.3390/nu10111738.

Chaudhari, N., Roper, S.D. (2010). The cell biology of taste. J Cell Biol, 190(3): 285-296, doi: $10.1083 /$ jcb.201003144.
Clegg, K.M., Lim, C.L., Manson, W. (1974). The structure of a bitter peptide derived from casein by digestion with papain. J Dairy Res, 41(2): 283287, doi: 10.1017/S0022029900019695.

Daliri, E.B-M., Oh, D.H., Lee, B.H. (2017). Bioactive peptides. Foods, 6(5): 32, doi: 10.3390/foods6050032.

Delgado-Martínez, F.J., Carrapiso, A.I., Contador, R., Ramírez, M.R. (2019). Volatile compounds and sensory changes after high pressure processing of mature "Torta del Casar" (raw ewe's milk cheese) during refrigerated storage. Innov Food Sci Emerg, 52: 34-41, doi: 10.1016/j.ifset.2018.11.004

Desmasures, N. (2014). Mold-Ripened Varieties. In: Encyclopedia of Food Microbiology, Batt, C.A. (Chief ed.), $2^{\text {nd }}$ Edition, Volume 1, the UK, pp. 409-415, doi: 10.1016/B978-0-12-3847300.00060-4.

Dorian, A.F. (ed.), (1978). Dictionary of science and technology. $1^{\text {st }}$ Edition, Elsevier Science Publishing, New York, the USA, 1411 p.

Fábián, T.K., Beck, A., Fejérdy, P., Hermann, P., Fábián, G. (2015). Molecular mechanisms of taste recognition: considerations about the role of saliva. Int J Mol Sci, 16(3): 5945-5974, doi: 10.3390/ijms16035945.

Favaro-Trindade, C.S., Santana, A.S., MonterreyQuintero, E.S., Trindade, M.A., Netto, F.M. (2010). The use of spray drying technology to reduce bitter taste of casein hydrolysate. Food Hydrocoll, 24(4): 336-340, doi: 10.1016/j.foodhyd.2009.10.012.

Foegeding, E.A., Davis, J.P. (2011). Food protein functionality: A comprehensive approach. Food Hydrocoll, 25: 1853-1864, doi: 10.1016/j.foodhyd.2011.05.008.

Gaudette, N.J., Pickering, G.J. (2013). Modifying bitterness in functional food systems. Crit Rev Food Sci Nutr, 53(5): 464-481, doi: 10.1080/10408398.2010.542511.

Ghnimi, S., Kamal-Eldin, A. (2015). Casein variants and challenges in the valorization of camel milk as a healthy alternative to cow milk. $J$ 
Bioequiv Availab, 7(4): 10000e67, doi: 10.4172/jbb.10000e67.

Giannoglou, M., Karra, Z., Platakou, E., Katsaros, G., Moatsou, G., Taoukis , P. (2016). Effect of high pressure treatment applied on starter culture or on semi-ripened cheese in the quality and ripening of cheese in brine. Innov Food Sci Emerg, 38: 312-320, doi: 10.1016/j.ifset.2016.07.024.

Grygier, A., Myszka, K., Rudzińska, M. (2017). Galactomyces geotrichum - moulds from dairy products with high biotechnological potential. Acta Sci Pol Technol Aliment, 16(1): 5-16, doi: 10.17306/J.AFS.2017.2017.0445.

Guichard, Salles, C. (2016). Retention and release of taste and aroma compounds from the food matrix during mastication and ingestion. In: Flavor From Food to Behaviors, Wellbeing and Health, Etiévant, P., Guichard, E., Salles, C., Voilley, A. (eds.), $1^{\text {st }}$ Edition, Woodhead Publishing, the UK, pp. 3-22, ISBN-10: 0081002955.

Guigoz, Y., Solms, J. (1976). Bitter peptides, occurrence and structure. Chem senses flavor, 2(1): 71-84, doi: 10.1093/chemse/2.1.71.

Haji, E., Yaacoub, R., Al-Arja, N., Scandar, S., Dib, H. (2019). Development of a culture-ripened semi-hard Kishk-cheese containing Bourghol or Semolina. J Food Res, 8(1): 21-31, doi: 10.5539/jfr.v8n1p21.

Jørgensen, C.E., Abrahamsen, R.K., Rukke, E-O., Hoffmann, T.K., Johansen, A-G., Skeie, S.B. (2019). Processing of high-protein yoghurt - a review. Int Dairy J, 88: 42-59, doi: 10.1016/j.idairyj.2018.08.002.

Karadeniz, F. (2000). Lezzet algilama mekanizmas1. Grda, 25(5): 317-324, ISSN: 13003070.

Karametsi, K., Kokkinidou, S., Ronningen, I., Peterson, D.G. (2014). Identification of bitter peptides in aged Cheddar cheese. I Agric Food Chem, 62(32): 8034-8041, doi: 10.1021/jf5020654.

Kazaz, C.., Ocak, M., Mesut, B., Özsoy, Y. (2019). Ağızda dağılan tabletlerde formülasyon tasarımı ve tat değerlendirilmesi. FABAD J Pharm Sci, 44(2): 169-178.
Kim, K-S., Egan, J.M., Jang, H-J. (2014). Denatonium induces secretion of glucagon-like peptide-1 through activation of bitter taste receptor pathways. Diabetol, 57: 2117-2125, doi: 10.1007/s00125-014-3326-5.

Krisch, J., Csanádi, J., Vágvölgyi, C. (2015). Fungi in and on dairy products. In: Fungi from Different Substrates, Misra, J.K., Tewari, J.P., Deshmukh, S.K., Vágvölgyi, C. (eds.), $1^{\text {st }}$ Edition, CRC Press, Boca Raton, pp. 159-169, doi: 10.1201/b17646.

Lee, K.D., Lo, C.G., Warthesen, J.J. (1996). Removal of bitterness from the bitter peptides extracted from Cheddar cheese with peptidases from Lactococcus lactis ssp. cremoris SK11. J Dairy Sci, 79(9): 1521-1528, doi: 10.3168/jds.S00220302(96)76512-8.

Lemieux, L. Simard, R.E. (1992). Bitter flavour in dairy products. II. A review of bitter peptides from caseins: their formation, isolation and identification, structure masking and inhibition. Lait, 72(4): 335-382, doi: 10.1051/lait:1992426.

Liu, X., Jiang, D., Peterson, D.G. (2014). Identification of bitter peptides in whey protein hydrolysate. J Agric Food Chem, 62(25): 5719-5725, doi: 10.1021/jf4019728.

Ma, J-J., Mao, X-Y., Wang, Q., Yang, S., Zhang, D., Chen, S-W., Li., Y-H. (2014). Effect of spray drying and freeze drying on the immunomodulatory activity, bitter taste and hygroscopicity of hydrolysate derived from whey protein concentrate. LWT - Food Sci Technol, 56(2): 296-302, doi: 10.1016/j.lwt.2013.12.019.

McSweeney, P.L.H. (2007). Cheese manufacture and ripening and their influence on cheese flavour. In: Improving the flavour of cheese, Weimer, B.C. (ed.), $1^{\text {st }}$ Edition, Woodhead Publishing, England, pp. 1-25.

Melis, M., Barbarossa, I.T. (2017). Taste perception of sweet, sour, salty, bitter, and umami and changes due to l-arginine supplementation, as a function of genetic ability to taste 6-npropylthiouracil. Nutrients, 9(6):E541, doi: 10.3390/nu9060541.

Meng, F., Chen, R., Zhu, X., Lu, Y., Nie, T., Lu, F., Lu, Z. (2018). Newly effective milk-clotting 
enzyme from Bacillus subtilis and its application in cheese making. J Agric Food Chem, 66: 6162-6169, doi: 10.1021/acs.jafc.8b01697.

Miişoğlu, D., Hayoğlu, İ. (2005). Tat eşik değerlerinin algilanması, tanınması ve derecelendirilmesi. J Agric Fac HR U, 9(2): 29-35.

Mohammadi, R., Mahmoudzadeh, M., Atefi, M., Khosravi-Darani K., Mozafari, M.R. (2015). Applications of nanoliposomes in cheese technology. Int J Dairy Technol, 68(1): 11-23, doi: 10.1111/1471-0307.12174.

Mohan, A., Udechukwu, M.C., Rajendran, S.R.C.K., Udenigwe, C.C. (2015). Modification of peptide functionality during enzymatic hydrolysis of whey proteins. RSC Adv, 5: 97400-97407, doi: 10.1039/C5RA15140F.

Nielsen, S.D., Jansson, T., Le, T.T., Jensen, S., Eggers, N., Rauh, V., Sundekilde, U.K., Sørensen, J., Andersen, H.J., Bertram, H.C., Larsen, L.B. (2017). Correlation between sensory properties and peptides derived from hydrolysed-lactose UHT milk during storage. Int Dairy J, 68: 23-31, doi: 10.1016/j.idairyj.2016.12.013.

Nuñez, M., Calzada, J., del Olmo, A. (2020). High pressure processing of cheese: Lights, shadows and prospects. Int Dairy J, 100: 104558, doi: 10.1016/j.idairyj.2019.104558.

Paul, M., Nuñez, A., Van Hekken, D.L., Renye, J.A.Jr. (2014). Sensory and protein profiles of Mexican Chihuahua cheese. J Food Sci Technol, 51(11): 3432-3438, doi: 10.1007/s13197-0120868-8.

Poveda, J.M., Cabezas, R.C.L. (2015). Biogenic amine content and proteolysis in Manchego cheese manufactured with Lactobacillus paracasei subsp. paracasei as adjunct and other autochthonous strains as starters. Int Dairy J, 47: 94-101, doi: 10.1016/j.idairyj.2015.03.004

Rauh, V.M., Johansen, L.B., Ipsen, R., Paulsson, R., Larsen, L.B., Hammershøj, M. (2014). Plasmin Activity in UHT milk: Relationship between proteolysis, age gelation, and bitterness. J Agric Food Chem, 62(28): 6852-6860, doi: 10.1021/jf502088u.
Saha, B.C., Hayashi, K. (2001). Debittering of protein hydrolyzates. Biotechnol Adv, 19(5): 355370, doi: 0.1016/s0734-9750(01)00070-2.

Sebald, K., Dunkel, A., Schäfer, J., Hinrichs, J., Hofmann, T. (2018). Sensoproteomics: A new approach for the identification of taste-active peptides in fermented foods. J Agric Food Chem, 66(42): 11092-11104, doi: 10.1021/ acs.jafc.8b04479.

Solms, J. (1969). The taste of amino acids, peptides, and proteins. J Agric Food Chem, 17(4): 686-688, doi: 10.1021/jf60164a016.

Stepaniak, L. (2004). Dairy enzymology. Int J Dairy Technol, 57(2/3): 153-171, doi: 10.1111/j.1471-0307.2004.00144.x.

Teixeira, P. (2014). Lactobacillus delbrueckii ssp. bulgaricus. In: Encyclopedia of Food Microbiology, Batt, C.A. (Chief ed.), $2^{\text {nd }}$ Edition, Volume 2, the UK, pp. 425-431, doi: 10.1016/B978-0-12-3847300.00060-4.

Thierry, A., Valence, F., Deutsch, S.-M., Even, S., Falentin, H., Loir, Y.L., Jan, G., Gagnaire, V. (2015). Strain-to-strain differences within lactic and propionic acid bacteria species strongly impact the properties of cheese-A review. Dairy Sci Technol, 95(6): 895-918, doi: 10.1007/s13594-015-0267-9.

Toelstede, S., Hofmann, T. (2008). Sensomics mapping and identification of the key bitter metabolites in Gouda cheese. J Agric Food Chem, 56(8): 2795-2804, doi: 10.1021/jf7036533.

Vummaneni, V., Nagpal, D. (2012). Taste masking technologies: An overview and recent updates. Int J Res Pharm Biomed Sci, 3(2): 510-524, ISSN: 2229-3701.

Widyastuti, Y., Lisdiyanti, P., Tisnadjaja, D. (2014). Role of Lactobacillus helveticus on flavor formation in cheese: Amino acid metabolism. Ann Bogor, 18(1): 1-11, doi: 10.14203/ann.bogor.2014.v18.n1.1-11.

Wu, C., Du, L., Zou, L., Zhao, L., Huang, L., Wang, P. (2014). Recent advances in taste celland receptor-based biosensors. Sensor Actuat BChem, 201: 75-85, doi: 10.1016/j.snb.2014.04.021. 
Yarlagadda, A.B. (2014). Assessment of different novel approaches to accelerate cheese ripening for a range of applications. Ph.D. Dissertation, University of Limerick, Limerick, Ireland, 350 p.

Yarlagadda, A.B., Wilkinson, M.G., O'Sullivan, M.G., Kilcawley, K.N. (2014). Utilisation of microfluidisation to enhance enzymatic and metabolicpotential of lactococcal strains as adjuncts in Gouda type cheese. Int Dairy J, 38(2): 124-132, doi: 10.1016/j.idairyj.2014.01.007. 